\title{
Kansei Factor in Developing Design of Women's Bag Materials of Combination of Doyo Woven Fabric and Genuine Leather
}

\author{
Dita Andansari ${ }^{1}$, Said Keliwar ${ }^{2}$, Heldina Pristanti ${ }^{3}$ \\ \{ditaandansari@polnes.ac.id ${ }^{1}$ \} \\ Product Design, Politeknik Negeri Samarinda, 75131, Samarinda ${ }^{1}$ \\ Tourism, Politeknik Negeri Samarinda, 75131, Samarinda ${ }^{2}$ \\ Business Administration, Politeknik Negeri Samarinda, 75131, Samarinda ${ }^{3}$
}

\begin{abstract}
East Kalimantan Typical Handicraft is one of the fields that has a major contribution in improving the regional economy. However, there are not much product developments have been carried out by the UKM Crafts in East Kalimantan. Meanwhile, special East Kalimantan handicraft products can contribute to one of the East Kalimantan Regional Medium-Term Development Plans, namely the development of ecotourism as souvenirs. The methodology used in this research was factor analysis is part of kansei engineering. From the research, it can be concluded that factors that influence people's preferences in choosing bags made of doyo woven fabric and genuine leather were the main factors: Emotional Appeal and Design with a variance of $29.003 \%$, color factor with a variance of $16.624 \%$, design details factor with a variance of $11.864 \%$ and material factor with a variance of $9.728 \%$.
\end{abstract}

Keywords: Bag, Factor, Doyo woven fabric, Genuine leather, East Kalimantan

\section{Introduction}

The creative economy industry in Indonesia provides the largest export contribution to Indonesia's Gross Domestic Product (GDP). Of the sixteen creative economy sub-sectors that exist, handicraft products are among the top three contributing sub-sectors. According to BPS data released by Bekraf, the biggest contributors to Indonesia's creative economy GDP in 2017 were the fashion sub-sector as much as $41.4 \%$, then culinary $17.6 \%$ and nearly $15 \%$ craft. These three sub-sectors are also the top contributor to Indonesia's exports. First, 41 fashion at US \$ 11,964 million, then crafts as much as US $\$ 6,000$ million (6 billion), only culinary at US $\$$ 1,300 million (1.3 billion). With so many contributions from craft and fashion products, there are still wide opportunities to always develop craft and fashion products. Craft products are of various types, ranging from wood crafts, metal crafts, textile crafts and other crafts. It is very interesting to develop craft products that also function as fashion.

East Kalimantan is one of the provinces in Indonesia which has various mainstay handicraft products which also contribute to the national GDP. These distinctive crafts include samarinda woven sarongs, beads, tumpar embroidery, ironwood crafts, rattan and doyo silk woven fabrics. The doyo ulap woven fabric is a superior craft in East Kalimantan because it has its own peculiarities, where the fiber is from the doyo plant which is widely grown in West Kutai. Initially, doyo weaving was used as traditional Dayak Benuaq clothing for events such as 
funerals and wedding ceremonies. Currently doyo weaving is growing both in terms of function and design, such as the shape of the motif and the color of the fabric. Ulap Doyo woven fabrics have been developed into fashion products such as bags, shoes, sandals and others. Previous research has been carried out on the development of fashion products from doyo woven fabrics, namely women's handbags. The development of women's handbags was made based on the results of research that gathered preferences or preferences from the community for women's handbags made from doyo woven fabrics in terms of bag elements such as bag handles, bag face cover shape, bag type, side joint of the bag and the type of material used. can be combined with doyo ulap woven fabric material. The results obtained are that the public prefers women's handbags made of doyo woven cloth with the handle with ring and round tabs, the cover is a flap with hidden magnetic closure, the pocket type is pocket with zippers, the sampler is button tabs. on sides and the combined type of material is genuine leather [1].

Product development research by looking at the preferences or choices of the user community is widely carried out today, such as: table clocks made of bamboo [2], coat designs [3] Malang handicraft products [4], baby bag design [5] rattan dining chair design [6], the development of an affective design methodology [7], a combination design of a rocking horse and a children's folding chair [8], watch design [9], apparel product design [10], textile motifs and colors [11], bag designs made of genuine leather [12].

There are no studies that discuss the factors that influence people's preferences / choices for women's handbags made from a combination of doyo and genuine leather based on the composition of the design. This research was conducted to find out what factor influence people's preferences for women's handbags made from a combination of doyo silk and genuine leather.

\section{Methods}

The method used in this research is Kansei engineering with the stages of preliminary research, collecting of kansei words, making questionnaire semantic differential I, distributing questionnaire semantic differential I and statistical I analysis.

\subsection{Product Design}

In this research, a new design of women's handbag made from a combination of doyo and genuine leather is designed based on the customer's kansei. However, before designing a new product design, first determine:

\subsubsection{The target groups}

Based on interviews with doyo caterpil ature studies on fashion products made from doyo, the market segmentation is based on age; late adolescents 17-25 years, early adults 26-35 years, late adults 36-45 years and early seniors $46-55$ years and gender; lar entrepreneurs as well as literwoman. 


\subsubsection{A niche markets}

The advantage of a women's handbag product made from a combination of doyo silk and genuine leather is that it is natural, where doyo silk and genuine leather are both environmentally friendly and strong.

\subsubsection{New product specifications}

At the end of the research, a product specification would be achieved in the form of a doyo ulcer application and genuine leather into a women's handbag product based on people's preferences / choices.

\subsection{Kansei Words}

The collection of Kansei Words takes place over sixteen days through:

\subsubsection{Interview and fill out a questionnaire}

Interviews conducted with customers of doyo ulap products were conducted both formallyinformally and directly-indirectly at various locations such as universities, housing estates, offices and others. The questionnaire was also filled out for 102 respondents.

\subsubsection{Reference from the designer website}

To enrich the kansei words obtained, they are taken from word references from social media related to fashion from ulap doyo such as Facebook Doyo Mungaq.

\subsubsection{Fashion designer}

There were consultations with fashion designers from Bandung, Mia Ratmelia, M. Ds and from Surabaya, Eri Naharani Ustaza, M. Ds, who is also the owner of the boutique Rahdia Kinan. From the results of this collection, a total of 66 kansei words for women's handbags made from a combination of doyo and genuine leather made into K-Cards before finally being grouped into category classification and designed as a Semantic Differential 1 questionnaire.

\subsection{Category Classification}

Category Classification is a method for reducing data by creating levels (levels) from the main concept to the sub-level concept. For Kansei Words Ulap Doyo in this study, of the kansei words found, the categorization was classified into 13 groups where each group contains about 2 to 10 kansei words. This category classification is determined based on grouping of similar words. The 13 groups of the kansei words are fashionable, ergonomic, picturesque, proud, thera are accessories, bright, light, character, unic, elegant, ethnic dominant, patterned and textured. At the initial stage, a grouping of kansei words is made. This grouping is done by means of equality and closeness of the meaning of words according to terms in the design field. 


\subsection{Differential semantic questionnaire 1}

In this questionnaire, respondents will assess the criteria for women's handbag products made from a combination of doyo ulcer and the desired genuine leather by providing an assessment of the pairs of kansei words using the Semantic Differential technique (SD Evaluation 1). The Kansei words that make up the SD 1 questionnaire 1 are the main concepts of the previous category classification. The following are pairs of kansei words used in the SD I questionnaire.

\section{Results and Discussion}

\subsection{Validity and reliability test}

After distributing the Semantic Differential, I questionnaire, valid adjectives were obtained, namely proud, picturesque, ergonomic, unic, elegant, ethnic dominant, little accessories, patterned, bright, textured and light (adjectives). From the calculation results, the reliability value for women's handbags made of a combination of doyo silk and genuine leather is 0.780 . So, it can be concluded that all variables in the questionnaire are said to be reliable.

After redistributing by eliminating fashionable and characteristic variables, the questionnaire was distributed to a number of 102 respondents, with validity and reliability calculations as follows. The validity test aims to determine whether a questionnaire is valid or not. A questionnaire is said to be valid if the question is able to reveal something that you want to measure in a study. The results of the conclusion of the validity test, it can be seen that all variables are valid because they have $r$ count $>r$ table $(0.202)$ and have a significance of less than 0.05 ( $5 \%$ error rate). So that all variables will be included in the next calculation process. Reliability test shows the consistency and stability of a score (measurement scale).

Reliability differs from validity in that it focuses on issues of consistency and is more concerned with issues of accuracy. The step in testing the reliability is to look at the crobach alpha value. If the Cronbach alpha value is $\geq 0.6$, the variable is said to be reliable (Ghozali, 2002). From the calculation results, the reliability value for women's handbags made of a combination of doyo silk and genuine leather is 0.710 . So, it can be concluded that all variables in the questionnaire are said to be reliable.

\subsection{Factor analysis}

In the Extraction Sums of Squared Loadings section [2] shows the number of variations or the number of factors that can be formed, in the output results above there are (two) variations of factors, namely $29.003 ; 14,624 ; 11,864$ and 9,728. From the rotated component matrix, there are formed factors, namely emotional appeal and design, color, design details and material.

The Extraction Sums of Squared Loadings section in Table 1 shows the number of variations or the number of factors that can be formed, in the output results above there are 4 (four) variation factors, namely $29.003 ; 14,624 ; 11,864$ and 9,728. 
Table 1. The extraction sums of squared loadings sections

\begin{tabular}{ccccccc}
\hline \multirow{2}{*}{ Component } & \multirow{2}{*}{ Total } & \multicolumn{3}{c}{ Initial Eigenvalues } & \multicolumn{3}{c}{ Extraction Sums of Squared Loadings } \\
\cline { 3 - 7 } & & \% of Variance & Cumulative \% & Total & \% of Variance & Cumulative \% \\
\hline 1 & 3.190 & 29.003 & 29.003 & 3.190 & 29.003 & 29.003 \\
2 & 1.609 & 14.624 & 43.627 & 1.609 & 14.624 & 43.627 \\
3 & 1.305 & 11.864 & 55.491 & 1.305 & 11.864 & 55.491 \\
4 & 1.070 & 9.728 & 65.219 & 1.070 & 9.728 & 65.219 \\
5 & .823 & 7.483 & 72.702 & & & \\
6 & .704 & 6.400 & 79.102 & & & \\
7 & .653 & 5.941 & 85.042 & & & \\
8 & .488 & 4.439 & 89.481 & & & \\
9 & .425 & 3.862 & 93.343 & & & \\
10 & .381 & 3.461 & 96.804 & & & \\
11 & .352 & 3.196 & 100.000 & & & \\
\hline
\end{tabular}

Thus, people's preference for bags made of doyo woven fabric and genuine leather is mainly influenced by emotional appeal and design, for example the beauty of the product, the uniqueness of the product, the comfort of the product, the elegance of the product and being interested because it is proud to have a bag made of products. doyo woven fabric and genuine leather.

The second factor that influences people to buy bags made of doyo woven fabric and genuine leather is the color factor, including the motif on the material. Meanwhile, design details factors such as the presence of bag accessories, whether or not the bag is light or not, and the material factor are the last things that people consider when buying bags made of 3 doyo woven fabric and genuine leather.

\section{Conclusion}

From the research, it can be concluded that factors that influence people's preferences in choosing bags made of doyo woven fabric and genuine leather were the main factors:

- Emotional Appeal and Design with a variance of $29.003 \%$,

- Color factor with a variance of $16.624 \%$,

- Design details factor with a variance of $11.864 \%$ and 39

- Material factor with a variance of $9.728 \%$.

\section{Acknowledgment}

Our gratitude goes to Samarinda State Polytechnic who has funded this research and also to the organizer of the Borobudur 2 international seminar who has provided an opportunity so that this research can participate. 


\section{References}

[1] D. Andansari and S. Kelewar, "Preferensi Masyarakat Kalimantan Timur Terhadap Pemilihan Produk Fesyen Berbahan Ulap Doyo," Jurnal Kreatif: Desain Produk Industri Dan Arsitektur, vol. 7, no. 1, 2019.

[2] A. Shergian and T. Immawan, "Design of innovative alarm clock made from bamboo with kansei engineering approach," Agriculture and Agricultural Science Procedia, vol. 3, pp. 184-188, 2015.

[3] H. Quan, S. Li, and J. Hu, "Product innovation design based on deep learning and kansei engineering," Applied Sciences, vol. 8, no. 12, p. 2397, 2018.

[4] R. Mochammad, S. Sudjito, S. Sugiono, and H. Sri, "The model selection for micro and small enterprises (MSEs) for handicraft product design innovation in Malang," Восточно-Европейский журнал передовых технологий, по. 2 (3), pp. 60-66, 2019.

[5] D. Janari and A. Rakhmawati, "Developing baby bag design by using Kansei engineering method," in IOP Conference Series: Materials Science and Engineering, 2016, vol. 105, no. 1, p. 012031: IOP Publishing.

[6] V. S. Johan, S. Rahardja, E. Gumbira-Said, T. Djatna, and K. B. W. Km, "Identifikasi Kansei Untuk Evaluasi Desain Produk Kursi Makan Rotan Kansei Identification For Rattan Dining Chair Design Evaluation"

[7] M. Hartono, "Kansei Mining-based in Services sebagai Alternatif Pengembangan Metodologi Affective Design," KELUWIH: Jurnal Sains dan Teknologi, vol. 1, p. 63, 02/28 2020.

[8] I. Prakoso and H. Purnomo, "Innovative design of the combined rocking horse toy and folding chair for children," Int. J. Adv. Sci. Eng. Inf. Technol, vol. 9, no. 5, 2019.

[9] H. Z. Novibrilliawan, "Wristwatch Development Based On Kansei Engineering," 2018.

[10] J. Rajasekera and H. Karunasena, "Apparel Design Optimization for Global Market: Kansei Engineering Preference Model," International Journal of Affective Engineering, vol. 14, pp. 119126, 03/31 2015.

[11] F.-L. CHANG and S.-S. GUAN, "A research of preference on patterns styles and color tones variations," International Journal of Affective Engineering, vol. 13, no. 3, pp. 185-195, 2014.

[12] N. Kongprasert, D. Brissaud, C. Bouchard, A. Aoussat, and S. Butdee, "The customer-oriented bag matrix to support the design leather bags," in 42nd CIRP Conference on Manufacturing Systems, 2009, pp. - . 